PROBLEMS

OF EDUCATION

IN THE $21^{\text {st }}$ CENTURY

Vol. 77, No. 6, 2019

688

\title{
SCIENTIFIC ARTICLE PREPARATION: A COMPREHENSIVE INTRODUCTION
}

\author{
Vincentas Lamanauskas \\ Šiauliai University, Lithuania \\ E-mail: vincentas.lamanauskas@su.It
}

Writing and publishing scientific articles (research, review, position etc. articles) are referred to as responsible academic activities. Any scientist/researcher is somehow involved in scientific writing. Thus, this is a technique assisting the researcher with demonstrating individual performance. Most of the main scientific/research journals are published in English, and therefore scientific information is made internationally available by a wide audience and actually becomes accessible to every scientist and/or researcher. On the other hand, a valid point is that scientific/research journals are published in different national languages. Nevertheless, it should be noted that science policy has recently become one-dimensional and resulting in a blind orientation towards support for scientific/research journals published in English. As noted by Poviliunas and Ramanauskas (2008), national languages face a legitimate risk of becoming domesticated and to one degree or another being excluded from scientific, cultural, education and public areas of life. However, this is material for another discussion.

Still, every researcher finds relevant to properly prepare a scientific article, i.e. describe the conducted research and publish the obtained results. The previous editorial attempts were made to discuss the fundamental structural elements of the scientific/research article, including the title, summary and keywords (Lamanauskas, 2019). This time, efforts are exerted to share certain insights and gained experience in writing the introduction to the article.

Prior to starting the article, each researcher does some preparatory work, which has a major impact on future work. The analysis of the already published scientific sources (research information) is of utmost importance. Consistent and detailed reading thus trying to delve and understand deeper the issues considered in the field of interest to the researcher seems to be the only option. Moreover, these aspects are important for writing a focused scientific/research article as well as for the justification of the presumed (planned) study, search for the research problem, etc. This is an efficient way to gain a broader view of research findings, the validity and reliability of the conducted study and the methods other researchers tried to apply in order to solve the encountered problems. Thus, possible contradictions, gaps in the research field under consideration, etc. can be accepted in a more appropriate way. In contrast, to substantiate our research, we can be more focused on relevant statements provided in the published articles and made conclusions as well as stay more concentrated on the issues that may seem not clear and/or comprehensive enough.

Hence, the question on the essence of the introduction arises. Researchers frequently regard this subject matter as a minor issue and pay scant attention to it. As a result, the introduction of the scientific article leads 'to nowhere', which is often noticed when reading and reviewing scientific/research manuscripts. The introduction is prepared as a completely separate part of the manuscript and poorly relates to the logic of the whole scientific/research article. However, the introduction is a supremely important part of the scientific/research article and acts as the 'entrance gate' to the entire study described (Shah, 2015).

In general, the introduction has to answer the fundamental question - why has the research/study been undertaken? The introduction should contextualize the study by indicating 
what and why has already been done locally and globally. Consequently, the other key questions we should try to answer in the introduction are as follows:

- What is the problem?

- Are there any existing and appropriate solutions?

- What is its main limitation?

- What is a researcher aimed at?

Thus, three main stages can be identified (Figure 1).

3) What do we know?

\section{2) What don't we know?}

1) Why did we do this research?

\section{Figure 1. Three main stages of the introduction.}

The elaborated position on the above stages shows that we first describe the available information. Then, we make an attempt to find out possibly unknown and doubtful facts or feel uncertain about certain matters. Finally, we formulate the overall purpose of the research (aim) and the research hypothesis/es and/or questions. However, this cannot be considered to be true in all situations. Subject to the type, purpose and research idea, the formulation of research hypothesis and/or questions is not considered an absolute attribute. A valid point is that when writing the introduction, we move from general data (i.e. context, common information on the investigated field, topic or a problem being studied) to more specific facts and figures. This is the method of substantiating the research problem thus claiming this is the issue to be solved. Some examples of the problem under investigation are presented below (Table 1). 
PROBLEMS

OF EDUCATION

IN THE $21^{\text {st }}$ CENTURY

Vol. 77 , No. 6, 2019

690

Table 1. The examples of problem description.

\begin{tabular}{|c|c|}
\hline Example & Comment \\
\hline $\begin{array}{l}\text { Problem of Research } \\
\text { ISPS assessment is crucial at the beginning of the lecture, it will diagnose the learning } \\
\text { objective achievement of the lab practical and other learning activities. Conventional lab practical } \\
\text { work have not been accommodated all science process skill especially skill of designing experiment } \\
\text { is very rare in student lab worksheet (Nuzulia et al, 2019). Such skill is even more changing for } \\
\text { inservice teachers in rural area (Adlim et al, 2014). Thereby this study aims to develop a valid ISPS } \\
\text { instruments for fundamental chemistry course to evaluate ISPS of freshmen students. }\end{array}$ & $\begin{array}{l}\text { The description } \\
\text { of the problem is } \\
\text { extremely vague. The } \\
\text { text is linguistically } \\
\text { questionable; the } \\
\text { future tense is in use. } \\
\text { The problem is hardly } \\
\text { disclosed. }\end{array}$ \\
\hline
\end{tabular}

\section{Problem of Research}

Dealing with the background above, the research problem of this study is: (1) How is the students' mathematical communication skill in solving a mathematics problem? The aim of this study was to analyze students' mathematical communication skills in solving a mathematics problem. In this study, the way the students solve mathematical problems, started from the discussion, identifying facts and data, converting narrative questions into mathematical symbols and notations are investigated.
The problem is described applying a single question, which is generally inappropriate. The purpose of the study is also unclear.
This research aims to fill this gap. Our research is conducted to empirically explore this relationship in $* * * * * * *$ school counselors. In view of the basic aim of the research, the following problems have been set: (1) Is there a statistically significant relationship between psychological well-being levels and empathy levels of ******** school counselors? (2) Do empathy levels significantly predict psychological well-being levels of $* * * * * * * *$ school counselors? In accordance with the aim and the problems of the research, the following null hypotheses were tested:
A typical example. The researcher is focused on describing the problem by formulating two questions. One sentence contradicts another. Measuring statistical relations is considered a problem.

A quite common situation when a research problem is defined by formulating questions, which is considered inappropriate. The example provides alternating terms 'study' and 'research'.

As a rule, the introduction ends with a clear formulation of the research aim and question (s). Thus, the introduction usually presents researchers` brief overview of what is supposed to be solved during the reported original research.

Next, some acceptable and unacceptable features of the introduction to the article are discussed (Table 2). 
Table 2. The acceptable and unacceptable features of the introduction section of the article.

\begin{tabular}{|c|c|}
\hline Unacceptable features & Acceptable features \\
\hline $\begin{array}{l}\text { The introduction contains a number of quotations } \\
\text { and references; sometimes with no actual needs; } \\
\text { The introduction is clearly too long, the so-called } \\
\text { 'common-knowledge-introduction'; } \\
\text { A wide range of varying educational terms and } \\
\text { concepts are noticeable and presented in the } \\
\text { concise form with a focus on the extremely poor } \\
\text { expression of individual researcher's attitudes; } \\
\text { Different statements are inadequately substantiated } \\
\text { or completely lack evidence in general; } \\
\text { The introduction resembles a textbook in the field } \\
\text { of education and repeats widely accepted truth } \\
\text { (knowledge, facts, etc.); } \\
\text { The introduction applies to some references for } \\
\text { researchers claims from the studies conducted in } \\
\text { different scientific areas; } \\
\text { The introduction has relatively superficial } \\
\text { argumentation; } \\
\text { In general, the introduction does not announce or } \\
\text { explain the research problem; } \\
\text { Literature overview appears to be very random in } \\
\text { the introduction; } \\
\text { Research aim is formulated prior to revealing the } \\
\text { research problem/idea/ concept; } \\
\text { Incorrect use of English (or other) language tenses } \\
\text { (for example, future tense); } \\
\text { The introduction is written in the imaginative and } \\
\text { emotional way; } \\
\text { The introduction contains plenty of personal } \\
\text { pronouns such as 'l', 'me', 'we', 'my', 'our', etc. }\end{array}$ & $\begin{array}{l}\text { The introduction contextualizes the conducted } \\
\text { research; } \\
\text { The local and global nature of research is clearly } \\
\text { revealed; } \\
\text { The question How does this relates to my work/ } \\
\text { research? is clearly answered; } \\
\text { The introduction begins with a clear statement of the } \\
\text { researcher's original position; } \\
\text { The introduction is of relatively appropriate/optimal } \\
\text { volume (approximately } 10-12 \% \text { of the whole article); } \\
\text { English (or other language) tenses are properly } \\
\text { matched (Present simple tense is used for } \\
\text { mentioning the basic facts, Present perfect - for } \\
\text { referring to the previous research done); } \\
\text { The introduction discloses the importance of the } \\
\text { research done and shows the goals the researcher } \\
\text { focuses on; } \\
\text { The question 'What is the issue/concern this } \\
\text { research addresses?' is clearly answered; } \\
\text { The introduction clearly stresses how particular } \\
\text { research is different from others; } \\
\text { The introduction clearly synthesizes the previous } \\
\text { studies in order to emerge the needs and originality } \\
\text { of the particular research; } \\
\text { Clearly describes the research problem (problem } \\
\text { field); } \\
\text { The main purpose and questions (if required) of the } \\
\text { study are properly articulated; } \\
\text { The introduction is written using the scientific } \\
\text { language, style, etc. }\end{array}$ \\
\hline
\end{tabular}


PROBLEMS

OF EDUCATION

IN THE $21^{\text {st }}$ CENTURY

Vol. 77, No. 6,2019

692

Table 3. The examples of starting the introduction.

\begin{tabular}{|c|c|}
\hline $\begin{array}{l}\text { Introduction } \\
\text { How can we intervene more successfully in the teaching-learning process? How } \\
\text { can we best adapt teaching to the students' needs? These shared concerns are fuelling } \\
\text { educational debates all around the world. Schools still are highly standardized in norms, } \\
\text { spaces, times, but also relating to students, teachers and knowledge (Barroso, 1995, }\end{array}$ & $\begin{array}{l}\text { The introduction is started } \\
\text { improperly. Two questions are } \\
\text { introduced. It is still not clear } \\
\text { whether these are questions about } \\
\text { research and what is the material } \\
\text { they are based on. The questions } \\
\text { are followed by a sentence with a } \\
\text { reference. }\end{array}$ \\
\hline Introduction & \multirow[b]{2}{*}{$\begin{array}{l}\text { The introduction starts using a very } \\
\text { vague language, sentence structure } \\
\text { is complex, the hierarchy of } \\
\text { concepts is questionable (training is } \\
\text { a part of education). }\end{array}$} \\
\hline $\begin{array}{l}\text { The development in the last decade in Europe polyphonic educational area, } \\
\text { harmonization of models of education and training at national levels with the requirements of } \\
\text { European Higher Education Area, development a common understanding of the content of } \\
\text { qualifications at bachelor and master's degrees in terms of learning outcomes actualized the } \\
\text { genesis of the competence movement in the EU, the USA. Australia and Ukraine. In the EU }\end{array}$ & \\
\hline Introduction & \multirow[b]{2}{*}{$\begin{array}{l}\text { The beginning of the introduction } \\
\text { is inappropriate. A number of } \\
\text { general reasoning and trivial stuff. } \\
\text { Duplicates compared to the article } \\
\text { summary are found. }\end{array}$} \\
\hline $\begin{array}{l}\text { A teacher, as one of the main actors of the educational process, or, more specific, of the } \\
\text { teaching process, has important assignments, that differ from those which marked the teachers' } \\
\text { role in the past. Nowadays, their role is being changed. The teacher is no longer just a mean for } \\
\text { the transfer of knowledge, being in the center of the teaching process. Now, students are } \\
\text { becoming the subjects of teaching process, and the teacher's role is to help, encourage, follow, } \\
\text { direct and advise them. This way, he becomes the organizer, the coordinator, the motivator, the } \\
\text { evaluator, the researcher and the reflective practitioner, }\end{array}$ & \\
\hline $\begin{array}{l}\text { There is a global consensus that 'the quality of teaching is a critical element in the } 21 \text { st century } \\
\text { learning' (Darling Hammond \& Libberman, } 2012 \text { p. } 151 \text { ). However, views on how to develop } \\
\text { quality teachers differ across countries. Darling Hammond and Libberman (2012) noted that those } \\
\text { leading countries that achieved the highest ranking in the Program in International Student } \\
\text { Assessment (PISA) such as Finland, Singapore, Canada, Netherlands, Australia have different } \\
\text { approaches towards preparing high quality teachers. Some countries (for example, Finland, } \\
\text { Singapore and Canada) focused on stringent recruitment with the teacher candidates having 'strong } \\
\text { academic qualification and a passion to teach' whilst 'some countries provide alternative pathways } \\
\text { into teaching that eventually lead the teacher candidates into becoming a teacher' (Darling } \\
\text { Hammond \& Libberman, 2012, p. 152). }\end{array}$ & $\begin{array}{l}\text { Inappropriate first paragraph of the } \\
\text { introduction is started with a quote } \\
\text { from a specific source and, with } \\
\text { reference to it, basically proceeds } \\
\text { to make an attempt to give certain } \\
\text { statements. }\end{array}$ \\
\hline
\end{tabular}

A scientific article is most frequently a strictly structured document, although it depends on a specific area of science. Thus, the introduction is also characteristic of a certain structure. A review of the previous research is sometimes written in a separate section such as 'Literature Review'. The theoretical justification of the problem under consideration can also be distinguished as a separate section, e.g. 'theoretical overview/framework'. Although this is basically justified, it should make more sense to divide the introduction into specific sections. In this case, both the analysis/review of the sources of scientific information and theoretical framework can be presented as the basic subsections, which mainly leads to the justification and description of the research methodology. It is common for researchers to ask the question like What is the difference between an introduction and a literature review? And the answer here should be rather simple, because the literature review is a part (usually the largest, most important) of your introduction.

Literature review is the theoretical basis for research and is aimed at describing and evaluating the previous studies. However, this does not mean it is only a brief description of the previously conducted research (quite common situation presented in the articles), because a critical review of the performed study is required thus summarizing the key approaches, ideas and problems. 
It is often a problem when the object and purpose of the research are not clearly formulated in the introduction. What is more, it is frequently stated that 'the article is aimed at...' one subject matter or another etc. An article as such is purposeless. The primary purpose of any article is to provide readers/users with a certain type of scientific information. According to Day and Sakaduski (2011), a scientific article is a printed, published report describing research results, and therefore it is not appropriate to interpret the purpose of the article in some other way. Nevertheless, the article is one of the forms of introducing and making public the results of research activities. Thus, the introduction identifies the object/subject (research focus) and purpose of the study performed. Some researchers point out that the subject of the study is highly dependent on the purpose of the article (Poviliūnas \& Ramanauskas, 2008). Still, the followed approach is wrong methodologically. First, the research problem is clearly defined. Following the formulated research problem, the subject of the specific research is selected, for example, a social educational process and/or situation, the field of social reality or public relations contain appropriate contradiction. The object of the research points to the area to which the research activity is directed. The aim (usually expressed in one sentence) of the carried out research should be clearly worded and consistent with the title of the research article. As mentioned above, the title of the article is a verbal expression of the research problem (Lamanauskas, 2019). Later, if necessary, the main aim of the research/study is specified into several goals that can form objectives / tasks.

Although the common practice of writing scientific articles shows that quite a lot of researchers focus on writing the introduction completely and immediately, this is not the case. Before starting with the major part of research description, only a part of the introduction needs to be written and includes the justification of the relevance of the study, the formulation of the main purpose and research questions. The rest can be written after the whole article has been completed with the clear logic of the article being prepared. After all, the introduction section of the article should be linked to conclusions. Hence, it is worth noting that the introduction has to

- attract reader's/user's attention;

- clearly disclose the reason and motivation of the carried out research;

- explain how the conducted research will possibly help the reader/user with solving a similar and/or related problem;

Upon writing the introduction section of the article, analysing it with the following key points in mind is recommended:

- research object, the main purpose (possible explanatory goals/objectives), primary hypotheses and/or research questions have to be clearly formulated in the case they are required;

- the basic contradictions are eliminated;

- the relevance and novelty of the research are fully disclosed;

- the main latest researches of the analyzed problem are exhaustively discussed.

In addition to the considered features of writing the introduction, the use of a proper language is of high importance. The text should not contain any unexplained abbreviations, emotional stress or mysterious and confounding expressions (Armağan, 2013). The text of the introduction should clearly distinguish between generally accepted statements and those provided by the author, the statements made by the author and cited authors (researchers) of the articles. On one hand, statements may be treated as very convincing or generally accepted, whereas on the other, they may seem less persuasive and rather questionable.

Thus, effort to write the introduction should focus on the reader in order to create a picture of the essence and significance of the research carried out. In other words, the introduction 
Vincentas LAMANAUSKAS. Scientific article preparation: A comprehensive introduction

PROBLEMS

OF EDUCATION

IN THE $21^{\text {st }}$ CENTURY

Vol. 77, No. 6,2019

694

should act as the Curriculum Vitae of the studied research problem. The researcher has to convince the reader/user that his/her research done is important and meaningful. Finally, the practical aspect should be taken into account, because every scientific article is published in one way or another. Hence, prior to going deeper into the content of a publication, the editor of an appropriate journal first assesses the structural parts of the article in which the introduction most likely largely determines whether the article will be accepted for evaluation and possible publication. Reviewer's assessment is also a salient point, because the reviewer represents readers/users. A reviewer's feedback on the submitted article is most frequently the reaction of an ordinary reader. No one will understand an article that may seem incomprehensible to the reviewer. In this case, the arguments that fail to convince the reviewer will hardly be strong enough in favour of the reader.

Regarding all above discussed aspects of writing the introduction section of the article, considering the specificity and requirements for a particular research publication play a significant role.

\section{Note}

Some examples have been taken from the manuscripts submitted for journals Journal of Baltic Science Education and Problems of Education in the $21^{\text {st }}$ Century.

\section{References}

Armağan, A. (2013). How to write an introduction section of a scientific article? Turkish Journal of Urology, 39(Suppl 1), 8-9. doi:10.5152/tud.2013.046.

Day, R. A., \& Sakaduski, N. (2011). Scientific English: A guide for scientists and other professionals, 3rd ed. Santa Barbara, California: ABC-CLIO, LLC.

Kvašytė R., \& Macienė, J. (2010). Mokslinio darbo pradmenys [Basics of scientific work]. Šiauliai: Šiaulių universiteto leidykla, $143 \mathrm{p}$.

Lamanauskas, V. (2019). Scientific article preparation: Title, abstract and keywords. Problems of Education in the 21st Century, 77(4), 456-462. https://doi.org/10.33225/pec/19.77.456.

Poviliūnas, A., \& Ramanauskas, J. (2008). Vadybos ir administravimo mokslinio straipsnio savitumai ir struktūra [Features and structure of scientific article in the management and administration sciences]. Vadybos mokslas ir studijos - kaimo verslu ir ju infrastruktūros plètrai = Management Theory and Studies for Rural Business and Infrastructure Development, 15(4), 6-13.

Shah, J. N. (2015). How to write 'introduction' in scientific journal article. Journal of Patan Academy of Health Sciences (JPAHS), 2(1), 1-2.

Received: October 10, 2019

Accepted: December 02, 2019

Vincentas Lamanauskas

$\mathrm{PhD}$, Professor, Senior Researcher, University of Šiauliai, Institute of Education, P. Visinskio Street 25-119, LT-76351 Siauliai, Lithuania.

E-mail: vincentas.lamanauskas@su.It

Website: http://www.lamanauskas.puslapiai.It/;

https://www.researchgate.net/profile/Vincentas_Lamanauskas

ORCID ID: http://orcid.org/0000-0002-4130-7899 